
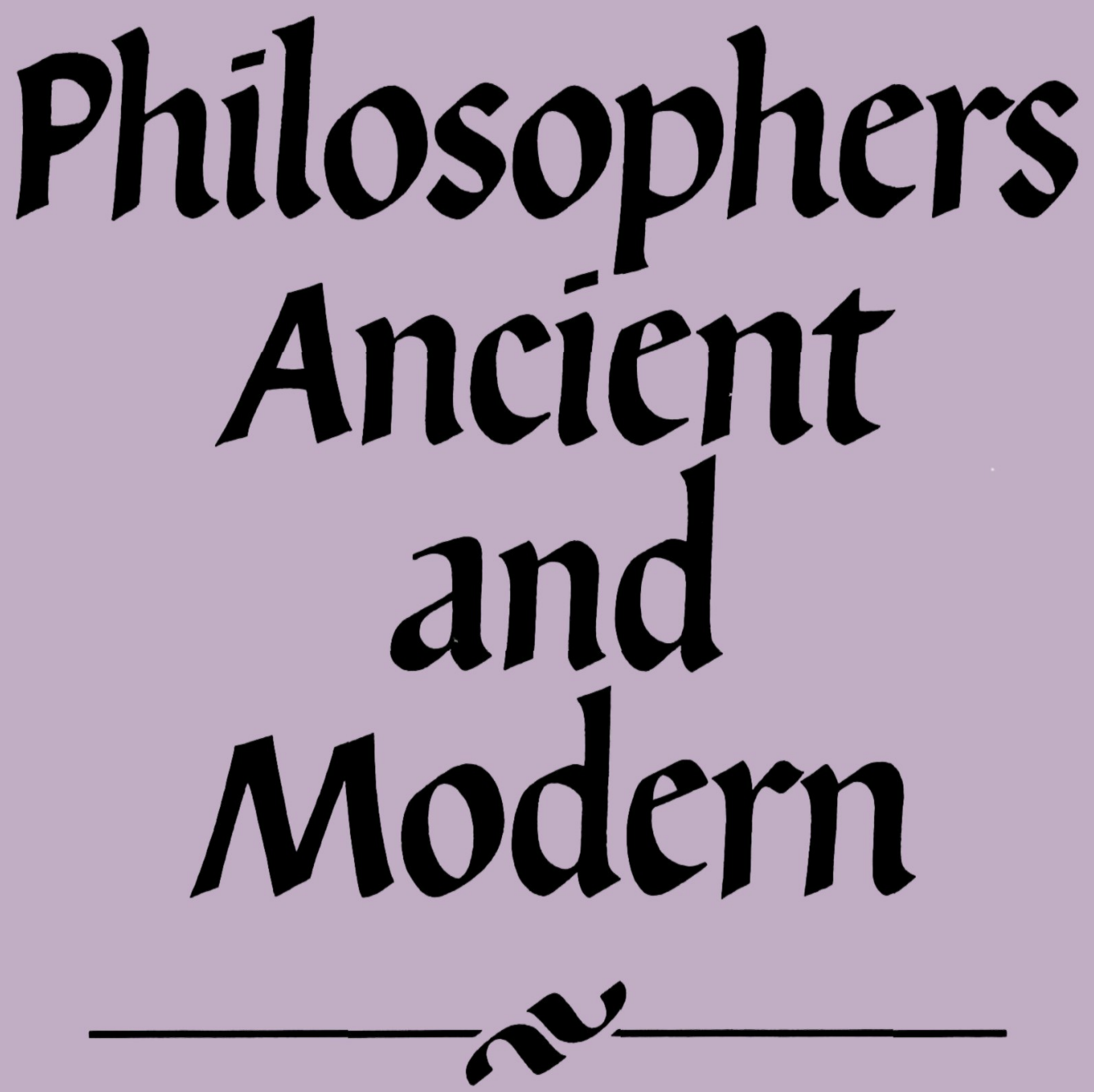

Edited by

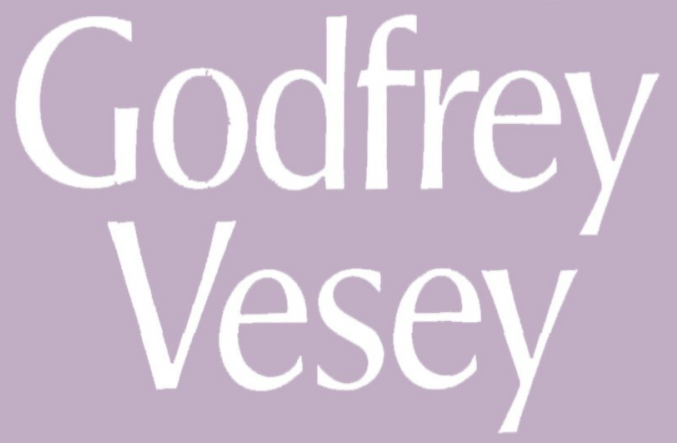




\title{
Philosophers Ancient and Modern
}

\author{
EDITED BY
}

\section{Godfrey Vesey}

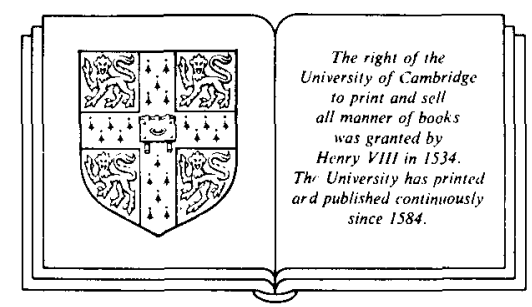

\section{CAMBRIDGE UNIVERSITY PRESS}

\section{CAMBRIDGE}

LONDON NEW YORK NEW ROCHELLE MELBOURNE SYDNEY 
Published by the Press Syndicate of the University of Cambridge The Pitt Building, Trumpington Street, Cambridge, CB2 1RP 32 East 57th Street, New York, NY 10022, USA 10 Stamford Street, Oakleigh, Melbourne 3166, Australia

(C) The Royal Institute of Philosophy 1986

Library of Congress catalogue card number: 86-17597

\section{British Library Cataloguing in Publication Data}

Philosophers ancient and modern.-(Royal Institute of

Philosophy lecture series; 20)

1. Philosophy, European

I. Vesey, Godfrey II. Philosophy III. Series $190^{\prime} .9 \quad$ B72

ISBN 0-521-33799-2

\section{Library of Congress Cataloguing in Publication Data}

Philosophers, ancient and modern.

(Royal Institute of Philosophy lecture series; 20)

"Supplement to Philosophy 1986."

Includes indexes.

1. Philosophy. I. Vesey, Godfrey Norman

Agmondisham. II. Annas, Julia. III. Philosophy. 1986 (Supplement) IV. Series.

B74.P48 $1986 \quad 100 \quad 86-17597$

ISBN 0-521-33799-2 (pbk.) 


\section{Contents}

Preface v v

Plato 1

Plato, Republic V-VII 3

JULIA ANNAS

Ethics in Plato's Republic 19

NICHOLAS DENYER

Aristotle 33

Aristotle, Nicomachean Ethics 35

ROSALIND HURSTHOUSE

René Descartes 55

Doubt, Knowledge and the Cogito in Descartes' Meditations 57 JOHN WATLING

Descartes' Sixth Meditation: The External World, 'Nature' and Human Experience JOHN COTTINGHAM

David Hume 91

Hume on Thought and Belief 93 EDWARD CRAIG

Hume on Liberty and Necessity 111 GODFREY VESEY

$\begin{array}{ll}\text { Hume's Philosophy of Religion } & 129\end{array}$ ANTONY FLEW

Karl Marx and Friedrich Engels 147

Marx and Engels, The German Ideology 149

C. J. ARTHUR

John Stuart Mill 169

Mill's Essay On Liberty 171 ALAN RYAN

Friedrich Nietzsche $\quad 195$

Nietzsche, Beyond Good and Evil 197 MICHAEL TANNER

Bertrand Arthur William Russell 217

Russell on Acquaintance $\quad 219$

R. M. SAINSBURY 


\section{Contents}

Russell on Universals 245

J. O. URMSON

Alfred Jules Ayer

259

Ayer, Language, Truth and Logic

OSWALD HANFLING

Jean-Paul Sartre

285

Sartre, Existentialism and Humanism

THOMAS BALDWIN

Index of Names 309

Index of Subjects 313 